\title{
Prediction of Seedling Emergence and Early Growth of Monochoria vaginalis and Scirpus juncoides under Elevated Temperature
}

\author{
Min-Won Park ${ }^{1}$, Jin-Won Kim ${ }^{1}$, Soo-Hyun Lim ${ }^{1}$, In-Yong Lee ${ }^{2}$ and Do-Soon Kim ${ }^{1 *}$ \\ 상승된 온도 조건에서 물달개비(Monochoria vaginalis)와 \\ 올챙이고랭이(Scirpus juncoides)의 출아 및 초기생장 예측
}

박민원 ${ }^{1}$, 김진원 ${ }^{1}$, 임수현 ${ }^{1}$, 이인용 ${ }^{2}$, 김도순 $^{*}$

\begin{abstract}
This experiment was conducted to investigate seedling emergence and early growth of Monochoria vaginalis and Scirpus juncoides in the controlled-environment chamber maintained at different temperatures. Non-linear regression analyses of observed data against effective accumulated temperature (EAT) with the Gompertz and logistic models showed that the Gompertz and logistic models worked well in describing seedling emergence and early growth of both weed species, respectively, regardless of temperature. EATs required for $50 \%$ of the maximum seedling emergence and the maximum leaf number of M. vaginalis were estimated to be 69.3 and $131^{\circ} \mathrm{C}$, respectively, while those of $S$. juncoides were 94.8 and $137^{\circ} \mathrm{C}$, respectively. Models developed in this study thus were used to predict seedling emergence and early growth under elevated temperature condition. If rotary tillage with water is made on 27 May under $+3{ }^{\circ} \mathrm{C}$ elevated temperature condition, dates for $50 \%$ of the maximum seedling emergence and 4 leaf stage were predicted to be 1 June and 15 June for M. vaginalis and 3 June and 14 June for S. juncoides, respectively. As compared with current temperature, these dates are 1-2 days earlier for the seedling emergence and 3 days earlier for the early growth, suggesting that earlier application of herbicides is required for effective control of $M$. vaginalis and $S$. juncoides under elevated temperature condition in the future.
\end{abstract}

\footnotetext{
${ }^{1}$ 서울대학교 농업생명과학대학 식물생산과학부, 151-742 서울특별시 관악구 관악로 599(Department of Plant Science, Seoul National University, Seoul 151-921, Korea).

${ }^{2}$ 농촌진흥청 국립농업과학원, 441-707 경기도 수원시 권선구 수인로 150(National Academy of Agricultural Science, RDA, Suwon 441-707, Korea).

* 연락저자(Corresponding author) : Phone) +82-2-880-4552, Fax)+82-2-873-2056, Email) dosoonkim@ snu.ac.kr
} 
Key words: early growth; elevated temperature; EAT; modelling; Monochoria vaginalis; Scirpus juncoides; seedling emergence.

\section{INTRODUCTION}

IPCC (2007) reported that atmospheric temperature increased by $0.74^{\circ} \mathrm{C}$ during last century and will further increase by $1.4 \sim 4.0^{\circ} \mathrm{C}$ in this century. Increasing temperature will affect not only crops but also weeds. Many studies have been conducted to investigate eco-physiological effects of elevated temperature and $\mathrm{CO}_{2}$ on crops (e.g. Jones et al. 2003; Tubiello et al. 2002) but not many on weeds. Although some studies dealt with weeds considering climate change (Moon et al. 2004; Kim et al. 2010), more works are required as there are so many weeds threatening crop production.

Monochoria vaginalis is an annual paddy weed distributed in China, Japan and Korea and known to be the most dominant paddy weed in Korea (Park et al. 2002). Although its competition effect on rice is not so high as compared with Echinochloa crus-galli (Moon 2010), it is still regarded as much important as E. crus-galli, particularly due to its resistance to sulfonylurea (SU) herbicides in Korea and Japan. Since its first report on herbicide resistance in Korea (Kwon et al. 2000), all the one-shot herbicides newly developed had to include herbicide which can control SU resistant M. vaginalis. Scirpus juncoides is a perennial sedge weed because it can overwinter in southern Korea and Japan. However, its main propagation is by seeds, so it can also be regarded as an annual weed. Like $M$. vaginalis, some of its biotypes were also reported to be resistant to SU herbicide (Ma et al., 2002). Therefore, it still remains as one of troublesome weeds in Korea and Japan although it is not strong competitor as compared with other perennial sedge weed Eleocharis kuroguwai (Moon 2010).
Leaf stage of target weed is one of the most important factors in weed management. If we could expect a specific leaf stage of the target weed, we can make a right decision for herbicide application in advance (Kim et al. 2010). Seedling emergence and early growth is affected by various factors complicatedly, but air temperature is most important factor (e.g. Steinbauer and Grigsby 1957; Pyon et al. 1990). Many studies of improving relationship between leaf stage and effective accumulated temperature (EAT) were conducted for effective and reasonable expecting of leaf stage (e.g. Morita 2000). EATs for 2 leaf stage of E. crus-galli and Aneilema keisak, the major annual paddy weeds in Korea was $127-128^{\circ} \mathrm{C}$ and $110-120^{\circ} \mathrm{C}$, respectively (Moon et al. 2004). Recently, EATs for seedling emergence and early growth of E. kuroguwai was also estimated by using the Gompertz model and observed field data (Kim et al. 2010). If such models using EAT can be developed, they can be utilized to predict seedling emergence and early growth under various temperature scenarios, so that timing for weed control can be advised appropriately.

Therefore, this study was conducted to predict seedling emergence and early growth of $M$. vaginalis and S. juncoides using a mathematical model based on EAT in order to advice appropriate timing for $M$. vaginalis and $S$. juncoides control in Korea based on IPCC's A1B scenario.

\section{MATERIALS AND METHODS}

\section{Data generation}

This experiment was conducted in the controlled- 
environment chamber (Conviron, Canada) at NAAS, RDA, Suwon in 2007. Seeds of M. vaginalis and $S$. juncoides were sown in a tray containing paddy soil. Pots were placed in the chamber maintained at $15 / 25,16.5 / 26.5$ and $18 / 28^{\circ} \mathrm{C}$ (day/night). Water depth was maintained to be $1 \mathrm{~cm}$ by regular top irrigation. Seedling emergence and early growth were recorded daily until 20 days after sowing. The experiment was consisted of three replicates in a completely randomized design.

\section{Model development and prediction}

The seedling emergence model describes mathematically the emergence pattern of seedlings, which is expressed as the time course of cumulative emergence. Although several models have been developed, the simplest and widely used model is Gompertz (1825) curve (e.g. Cussans et al. 1996; Kim et al. 2006),

$$
Y_{(T)}=\frac{C}{e^{e^{-B(T-M)}}}
$$

where $\boldsymbol{Y}$ is the accumulated seedling emergence at days $(\boldsymbol{T})$ after sowing. $\boldsymbol{C}$ is the maximum seedling emergence, $\boldsymbol{B}$ is the rate of increase of seedling emergence once it is initiated and $\boldsymbol{M}$ is a time lag to reach $50 \%$ of the maximum seedling emergence. In this case, parameters will be affected by air temperature, particularly parameters $\boldsymbol{M}$. Therefore, the later the planting date, the earlier the seedling will be as later planting will allow sown seeds to be exposed to higher temperature in a given period of time than earlier planting. However, if EAT is used instead of days after sowing as an independent variable, parameters may be no or less affected by planting date. Therefore eqn 1 can be rewritten by using $\operatorname{EAT}(t)$ as follows,

$$
Y_{(t)}=\frac{C}{e^{e^{-B\left(t-m_{e}\right)}}}
$$

where $\boldsymbol{m}_{e}$ is a EAT required to reach $50 \%$ of the maximum seedling emergence.

The logistic model has also been widely used to describe many biological events including soil depth effects on seedling emergence (Kim et al. 2006), herbicide effects (Streibig 1980; Kim et al. 2002) and early growth of plants.

$$
Y_{(t)}=\frac{C}{1+\left(\frac{t}{m_{g}}\right)^{B}}
$$

where $\boldsymbol{Y}$ is the growth of plant in number of leaf, plant height or dry matter, $t$ is the EAT after sowing, $\boldsymbol{C}$ is the maximum leaf number, $\boldsymbol{B}$ is the rate of increase of plant growth once it is initiated and $\boldsymbol{m}_{g}$ is a time lag to reach $50 \%$ of the maximum leaf number.

\section{Statistical analysis}

Non-linear regression analysis was conducted to fit the Gompertz model to observed seedling emergence and the logistic model to observed leaf number. All the statistical analyses were conducted by using Genstat 5 release 4.1 (Genstat 5 Committee, 1997).

\section{RESULTS AND DISCUSSION}

\section{Seedling emergence}

Seedling emergences of both weed species were plotted against days after sowing, showing that the higher the air temperature, the earlier their seedling emergences are (Fig. 1). When seedling emergence 


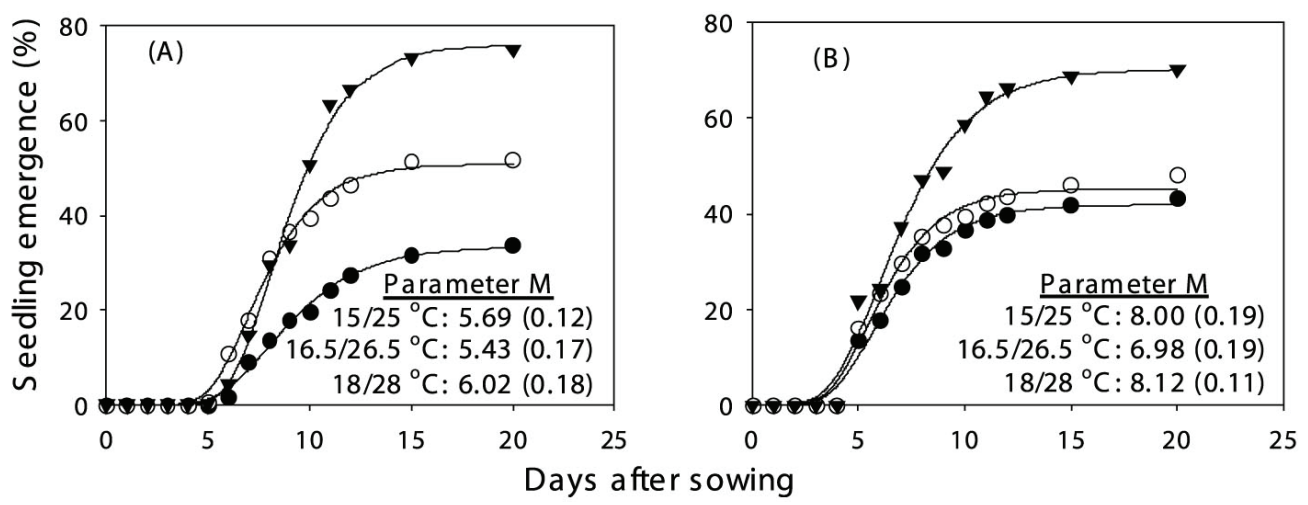

Fig. 1. Seedling emergence (\%) of M. vaginalis (A) and S. juncoides (B) at $15 / 25(\bullet), 16.5 / 26.5(\circ)$ and $18 / 28^{\circ} \mathrm{C}$ $(\boldsymbol{\nabla})$ of day/night temperature regimes. The continuous lines are fitted seedling emergence versus days after planting by using the Gompertz model and their parameter estimates. The parameter $\boldsymbol{M}$ indicates the time lag to reach $50 \%$ of the maximum seedling emergence.

Table 1. Parameter estimates for the seedling emergence of M. vaginalis and S. juncoides for the Gompertz model. The numbers in parentheses are standard errors.

\begin{tabular}{ccccc}
\hline \multirow{2}{*}{ Weed species } & \multicolumn{3}{c}{ Parameter estimates } & $\mathrm{R}^{2}$ \\
\cline { 2 - 4 } & $\mathrm{B}$ & $\mathrm{M}$ & $\mathrm{C}$ & 0.880 \\
Monochoria vaginalis & 0.0335 & 69.3 & 56.4 & $(1.7)$ \\
Scirpus juncoides & $(0.0032)$ & $(1.9)$ & 60.5 & 0.857 \\
& 0.0316 & 94.8 & $(2.5)$ & \\
\hline
\end{tabular}

was modelled with the Gompertz model by plotting seedling emergence versus days after planting, parameter $\boldsymbol{M}$ (a time lag to reach $50 \%$ of the maximum seedling emergence) was fluctuated with temperature (Fig. 1). To minimize such fluctuations in parameter $M$ with temperature, EAT was used as an

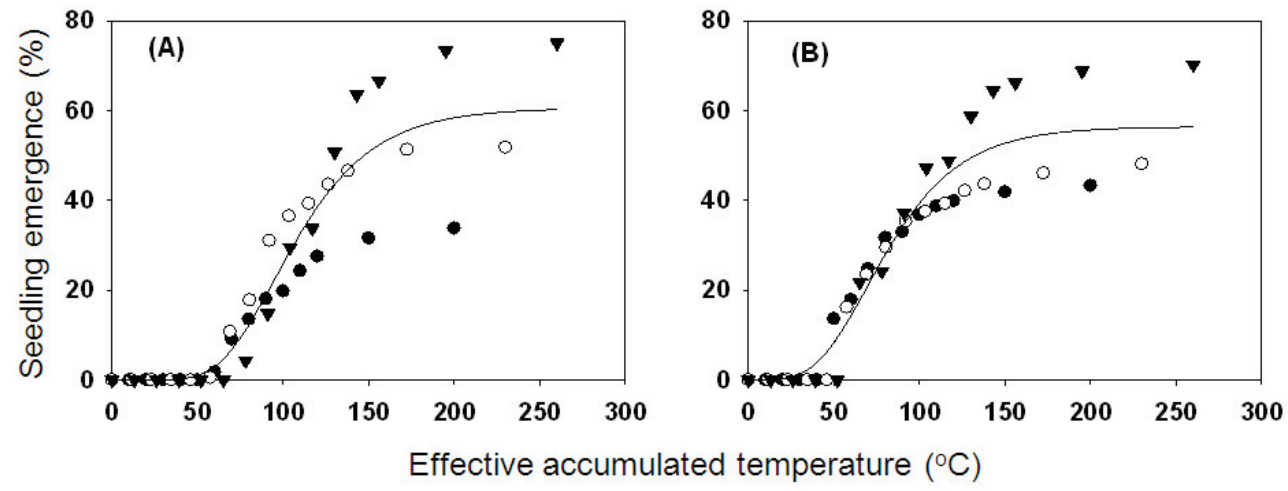

Fig. 2. Seedling emergence (\%) of M. vaginalis (A) and S. juncoides (B) at in $15 / 25(\bullet), 16.5 / 26.5(\circ)$ and $18 / 28^{\circ} \mathrm{C}$ $(\boldsymbol{\nabla})$ of day / night temperature regimes. The continuous lines are fitted seedling emergence versus days after planting by using the Gompertz model and their parameter estimates in Table 1. 
Table 2. Parameter estimates for the early growth in leaf number of M. vaginalis and S. juncoides for the logistic model. The numbers in parentheses are standard errors.

\begin{tabular}{ccccc}
\hline \multirow{2}{*}{ Weed species } & \multicolumn{3}{c}{ Parameter estimates } & $\mathrm{R}^{2}$ \\
\cline { 2 - 4 } & $\mathrm{B}$ & $\mathrm{M}$ & $\mathrm{C}$ & 0.923 \\
\hline Monochoria vaginalis & 0.0297 & 131.1 & 3.7 & \\
& $(0.0012)$ & $(2.0)$ & $(0.06)$ & 0.953 \\
Scirpus juncoides & 0.0270 & 137.4 & 5.3 & $(0.08)$ \\
\hline
\end{tabular}

independent variable to model seedling emergence of $M$. vaginalis and $S$. juncoides at different tem perature regimes. Seedling emergence of $M$. vaginalis and $S$. juncoides against EAT was well explained by the Gompertz model with less changes in the parameter $\boldsymbol{m}_{e}$ (EAT required to $50 \%$ of the maximum seedling emergence) with temperature as compared with plotting against days after sowing (Fig. 2). The parameter $m_{e}$ values (EATs required for $50 \%$ of the maximum seedling emergence of $M$. vaginalis and $S$. juncoides) were estimated to be 69.3 and $94.8^{\circ} \mathrm{C}$, respectively (Table 1 ).

\section{Number of leaf}

Leaf number was also fitted to the logistic model with EAT to model early leaf development of $M$. vaginalis and $S$. juncoides at different temperature regimes. The logistic model also well described the early leaf development of $M$. vaginalis and $S$. juncoides with EAT. The parameter $\boldsymbol{m}_{g}$ (EATs for $50 \%$ of the maximum leaf number) was estimated to be 131.1 and $137.4^{\circ} \mathrm{C}$ for $M$. vaginalis and $S$. juncoides, respectively (Fig. 3). Based on the model and its parameter estimates, EAT required for a specific leaf stage of $M$. vaginalis and $S$. juncoides can be estimated. For example, EATs required for 4 leaf stage were estimated to be 247 and $234^{\circ} \mathrm{C}$, respectively (Table 2). These estimated EAT can be used to predict dates reaching the specific leaf stage under various temperature conditions.

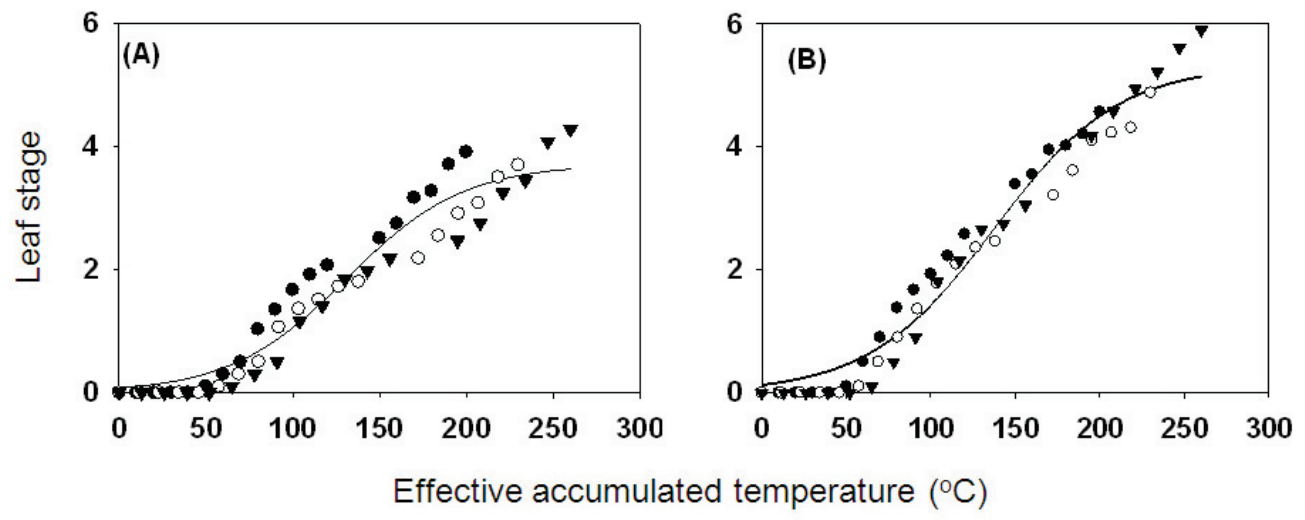

Fig. 3. Leaf stage of $M$. vaginalis (A) and $S$. juncoides (B) at $15 / 25(\bullet), 16.5 / 26.5(\circ)$ and $18 / 28^{\circ} \mathrm{C}$ ( $\mathbf{\nabla}$ ) of day / night temperature regimes. The continuous lines are fitted leaf stage by using the logistic model and their parameter estimates in Table 2. 
Table 3. Estimated dates for $50 \%$ of the maximum seedling emergence and 4 leaf stage of M. vaginalis and S. juncoides under current and $+3{ }^{\circ} \mathrm{C}$ elevated temperatures in Suwon if rotary tillage with water is made on 27 May.

\begin{tabular}{cccc}
\hline \multirow{2}{*}{ Target stage } & Temperature & \multicolumn{2}{c}{ Weed species } \\
\cline { 3 - 4 } & & Monochoria vaginalis & Scirpus juncoides \\
\hline $50 \%$ of the max. & Present & 2 June & 5 June \\
seedling emergence & $+3^{\circ} \mathrm{C}$ & $1 \mathrm{June}$ & $3 \mathrm{June}$ \\
& Difference* & $\nabla 1$ & $\nabla 2$ \\
& Present & 18 June & 17 June \\
4 leaf stage & $+3^{\circ} \mathrm{C}$ & 15 June & $\nabla 3$ \\
\hline
\end{tabular}

\section{Prediction of seedling emergence and early growth under elevated temperature}

Based on seedling emergence and leaf growth models from this experiment, dates reaching 50\% seedling emergence and 4 leaf stage were predicted in present and $3^{\circ} \mathrm{C}$ elevated temperature condition (Table 3). For example, if rotary tillage with water of paddy field is made on 27 May, M. vaginalis and $S$. juncoides will reach $50 \%$ of their maximum seedling emergence by 1 June and 3 June under 3 ${ }^{\circ} \mathrm{C}$ elevated condition, respectively, which is about 1 and 2 days earlier than current temperature condition. They will also grown up to 4 leaf stage by 15 June and 14 June under $3^{\circ} \mathrm{C}$ elevated condition, respectively, which is about 3 days earlier than current temperature condition. Therefore, these results suggest that weed control measure should be made earlier under elevated temperature condition in the future as both seedling emergence and early growth of $M$. vaginalis and $S$. juncoides will be facilitated.

Our study confirmed that elevated temperature affected both seedling emergence and early growth of both weed species. However, when we make a decision for herbicide application timing, we need to consider herbicide activity as elevated temperature may also affect herbicide activity against these weed species. In general, herbicide activity improves with increasing temperature (e.g., Ichizen et al. 1996) although there are some exemptions (e.g., Lee et al. 2006). As shown in Table 3, herbicide application needs to made earlier under elevated temperature. However, further works must be conducted to investigate the effects of elevated temperature on herbicide activity against these weeds and rice grown elevated temperature prior to making a final decision when to apply herbicide.

In conclusion, our work clearly demonstrates that seedling emergence and early growth of both weed species were well described by the Gompertz model and the logistic model, respectively, by plotting them against EAT. The models developed will be utilized for predicting dates for seedling emergence and early growth under elevated temperature, which will help to make a decision for herbicide application timing.

\section{요 약}

일년생 잡초인 물달개비 및 올챙이고랭이의 출아 와 초기생장을 예측하기 위한 모델 구축을 위하여 온 도조건을 달리한 식물생장상에서 포트실험을 수행하 였다. 이들 잡초의 출아 및 초기생장과 유효적산온도 와의 관계를 비선형회귀로 분석한 결과 온도조건에 상관없이 각각 Gompertz 모델 및 logistic 모델로 설 명이 잘 되었다. 물달개비 및 올챙이고랭이의 최대 
출아율의 $50 \%$ 에 필요한 유효적산온도는 각각 69.3 및 $94.8^{\circ} \mathrm{C}$ 이었으며, 4 엽기에 이르는데 필요한 유효 적산온도는 각각 247 및 $234^{\circ} \mathrm{C}$ 이었다. 본 연구에서 개발된 모델로 분석한 결과 평균 기온이 $3{ }^{\circ} \mathrm{C}$ 상승하 게 되면 이들 잡초의 $50 \%$ 출아는 물달개비의 경우 1 일, 올챙이고랭이의 경우는 2 일 빨라지고, 4 엽기에 다 다르는 날짜는 이들 잡초 모두 3 일이 빨라질 것으로 예측되었다. 따라서 온도상승조건에서 물달개비 및 올챙이고랭이를 효과적으로 방제하기 위해서는 현재 의 처리시기보다 약 2-3일 빨라져야 할 것으로 예상 된다.

\section{ACKNOWLEDGEMENTS}

This research was jointly supported by "Cooperative Research Program for Agriculture Science \& Technology Development (Project No. 200807A01081012)”, Rural Development Administration, and Technology Development Program for Agriculture and Forestry (Project code : 309009-05-1-SB010), Ministry for Food, Agriculture, Forestry and Fisheries, Republic of Korea.

\section{REFERENCES}

Cussans, G. W., S. Raudonius, P. Brain and S. Cumberworth. 1996. Effect of depth of seed burial and soil aggregate size on seedling emergence of Alopecurus myosuroides, Galium aparine, Stellaria media and wheat (Triticum aestivum L.). Weed Res. 36:122-142.

Gompertz, B. 1825. On the nature of the functions expressive of the law of human mortality, and on a new mode of determining the value of life contingencies. Philos. Trans. 115:513-585.

Genstat 5 Committee. 1997. Genstat 4 Release 4.1 : Reference manual supplement to Genstat 5
Committee (1993) Genstat 5 Reference manual Release 3. Numerical Algorithms Group, Oxford, UK.

Ichizen, N., T. Takeuchi, H. Omokawa, M. Knnnai and T. Takematu. 1991. Effect of soil type, water depth, water leakage and temperature of flowable and granular formulations of herbicides. Weed Res. Jpn. 36(4):338-342.

IPCC. 2007. Special report of the Intergovernmental Panel on Climate Change, CD-ROM.

Jones, P. G., and P. K. Thornton. 2003. The potential impacts of climate change on maize production in Africa and Latin America in 2055. Global Environ. Change. 13:51-59.

Kim, D. S., P. Brain, E. J. P. Marshall and J. C. Caseley. 2002. Modelling herbicide dose and weed density effects on crop : weed competition. Weed Res. 42:1-13.

Kim, D. S., Y. W. Kwon and B. W. Lee. 2006. The experiment was consisted of three replicates in a completely randomized design. Kor. J. Crop Sci. 51(4):362-368.

Kim, J. W., B. C. Moon, S. H. Lim, J. H. Chung and D. S. Kim. 2010. Prediction of seedling emergence and early growth of Eleocharis kuroguwai Ohwi under elevated temperature. Kor. J. Weed Sci. 30(2)(in press).

Kwon O. D., S. J. Koo, J. S. Kim, D. J. Lee, H. J. Lee, T. S. Park, Y. I. Kuk and J. O. Guh. 2000. Herbicide response and control of sulfonylurearesistant biotype of Monochoria vaginalis in paddy fields in Chonnam province, Korea. Kor. J. Weed Sci. 20(1):46-52.

Lee, J. N., D. S. Kim, K. H. Hwang and S. J. Koo. 2006. Environmental factors affecting the herbicide performance of flucetosulfuron. Kor. J. Weed Sci. 26(1):1-9.

Ma S. Y., S. L. Ko and S. S. Han. 2002. Resistance of Scirpus juncoides Roxb. biotype to sulfo- 
nylurea herbicides. Kor. J. Weed Sci. 22(4): 334-342.

Moon, B. C., J. S. Park, I. Y. Lee, J. U. Park, O. D. Kwon and Y. I. Kuk. 2004. Effect of several temperature conditions on germination and leaf development response of paddy weeds. Kor. J. Weed Sci. 24(3):206-213.

Moon, B. C. 2010. Modelling weed competition and herbicide effects on rice and decisionmaking for weed control in transplanted rice cultivation. PhD thesis, Seoul National University, Korea.

Morita, H. 2000. Forecast of leaf emergence by accumulated efficient air temperature in barnyardgrass. Kor. J. Weed Sci. 20(supplement 1):19-26.

Park J. E., I. Y. Lee, B. C. Moon, C. S. Kim, T. A. Park, S. T. Lim, J. R. Cho, S. M. Oh, I. B. Im, J. B. Hwang and Y. C. Ku. 2002. Occurrence characteristics and dynamics of weed flora in paddy rice field. Kor. J. Weed Sci. 22(3):272279.

Pyon, J. Y., T. G. Kang, C. W. Park and K. S. Kang. 1990. Effect of soil temperature and planting depth on emergence and growth of perennial paddy weeds. Kor. J. Weed Sci. 10(3):197-201.

Steinbauer G. P., and B. Grigsby. 1957. Interaction of temperature, light, and moistening agent in the germination of weed seeds. Weeds 5(3): 175-182.

Streibig, J. C. 1980. Models for curve fitting herbicide dose response data. Acta Agric. Scandi. 30:59-64.

Tubiello, F. N., C. Rosenzweig, R. A. Goldburg, S. Jagtap and J. W. Jones. 2002. Effects of climate change on US crop production : simulation results using two different GCM scenarios. Part I : Wheat, potato, maize, and citrus. Climate Res. 20:259-270. 